\title{
PRYWATNE POŚREDNICTWO PRACY A ŚWIADCZENIE USLUG INFORMACYJNYCH O MIEJSCACH PRACY ZA POŚREDNICTWEM SYSTEMÓW TELEINFORMATYCZNYCH
}

\begin{abstract}
Streszczenie. Treść art. 18 ust. 1 pkt 1 oraz art. 18c ust. 2 pkt 4 ustawy z dnia 20 kwietnia 2004 r. o promocji zatrudnienia i instytucjach rynku pracy, z uwagi na ich daleko idącą niedookreśloność, rodzi pytanie o to, jaka jest wzajemna relacja obu tych regulacji, w szczególności, czy usługi wymienione w art. 18c ust. 2 pkt 4 wskazanej ustawy mieszczą się w zakresie pojęciowym pośrednictwa pracy czy też przeciwnie, stanowią one usługi, których nie można zakwalifikować jako pośrednictwo pracy. W artykule szczegółowo przeanalizowano regulacje związane z gromadzeniem (w postaci dokumentu elektronicznego) i udostępnianiem informacji o wolnych i poszukiwanych miejscach pracy za pośrednictwem systemów teleinformatycznych. Ukazano różnicę między biernym i czynnym pośrednictwem pracy, a także podjęto próbę wskazania reżimu prawnego umowy o świadczenie usług wymienionych w art. 18c ust. 2 pkt 4 wskazanej wyżej ustawy.
\end{abstract}

Słowa kluczowe: pośrednictwo pracy, usługi informacyjne, system teleinformatyczny, dokument elektroniczny, zatrudnienie.

\section{UWAGI WSTĘPNE}

Problematyka stosowania umów cywilnoprawnych w świetle przepisów prawa pracy nie powinna ograniczać się wyłącznie do zatrudnienia niepracowniczego typu cywilnoprawnego i jego relacji względem zatrudnienia pracowniczego czy też do kwestii dotyczących umów cywilnoprawnych bezpośrednio lub pośrednio związanych ze stosunkiem pracy (np. przedwstępnej umowy o pracę, umowy o zakazie konkurencji po ustaniu stosunku pracy). W szczególności przedmiotem rozważań w ramach tak określonego tematu badawczego powinny być także zagadnienia związane z zawieraniem umów cywilnoprawnych, w ramach których świadczone są usługi rynku pracy określone w ustawie z dnia 20 kwietnia 2004 r. o promocji zatrudnienia i instytucjach rynku pracy (tekst jedn. Dz.U. z 2019 r., poz. 1482 ze zm.) (dalej: PromZatrU).

Zgodnie z art. 18 ust. 1 pkt 1 PromZatrU prowadzenie działalności gospodarczej w zakresie świadczenia usług pośrednictwa pracy (tzw. prywatne pośrednictwo pracy), obok usług doradztwa personalnego, poradnictwa zawodowego oraz

* Uniwersytet Śląski w Katowicach, Wydział Prawa i Administracji, Katedra Prawa Pracy i Polityki Socjalnej, michal.baranski@us.edu.pl. Radca prawny. 
pracy tymczasowej, jest działalnością regulowaną i wymaga wpisu do rejestru podmiotów prowadzących agencje zatrudnienia. Wśród przykładowych usług pośrednictwa pracy ustawodawca we wskazanym przepisie wymienił: (a) udzielanie pomocy osobom w uzyskaniu odpowiedniego zatrudnienia lub innej pracy zarobkowej oraz pracodawcom w pozyskaniu pracowników o poszukiwanych kwalifikacjach zawodowych; (b) pozyskiwanie i upowszechnianie ofert pracy; (c) udzielanie pracodawcom informacji o kandydatach do pracy, w związku ze zgłoszoną ofertą pracy; (d) informowanie kandydatów do pracy oraz pracodawców o aktualnej sytuacji i przewidywanych zmianach na lokalnym rynku pracy; (e) inicjowanie i organizowanie kontaktów osób poszukujących odpowiedniego zatrudnienia lub innej pracy zarobkowej z pracodawcami; (f) kierowanie osób do pracy za granicą u pracodawców zagranicznych, o którym mowa w art. 85 PromZatrU; (g) kierowanie cudzoziemców do zatrudnienia lub innej pracy zarobkowej do podmiotów prowadzących działalność na terytorium Rzeczypospolitej Polskiej, o którym mowa w art. 85a PromZatrU.

Z kolei stosownie do art. 18c ust. 2 pkt 4 PromZatrU nie wymaga wpisu do rejestru podmiotów prowadzących agencje zatrudnienia między innymi „gromadzenie w postaci dokumentu elektronicznego i udostępnianie informacji o wolnych i poszukiwanych miejscach pracy za pośrednictwem systemów teleinformatycznych".

Wstępna analiza treści obu przytoczonych wyżej przepisów, z uwagi na ich daleko idącą niedookreśloność, przede wszystkim rodzi pytanie to, jaka jest wzajemna relacja obu tych regulacji, w szczególności czy usługi wymienione w art. 18c ust. 2 pkt 4 PromZatrU mieszczą się w zakresie pojęciowym pośrednictwa pracy czy też wręcz przeciwnie, stanowią usługi, których nie można zakwalifikować jako pośrednictwo pracy? Udzielenie odpowiedzi na tak sformułowane pytania nie tylko ułatwi stosowanie przedmiotowych regulacji w kontekście wymogów ustawowych dotyczących prowadzenia działalności regulowanej, ale jednocześnie też określi reżim prawny umowy, której przedmiotem są usługi wymienione w art. $18 \mathrm{c}$ ust. 2 pkt 4 PromZatrU.

\section{GROMADZENIE W POSTACI DOKUMENTU ELEKTRONICZNEGO I UDOSTĘPNIANIE INFORMACJI O WOLNYCH I POSZUKIWANYCH MIEJSCACH PRACY ZA POŚREDNICTWEM SYSTEMÓW TELEINFORMATYCZNYCH}

W pierwszej kolejności omówienia wymagają praktycznie wszystkie pojęcia zamieszczone w art. 18c ust. 2 pkt 4 PromZatrU, albowiem ich zakresy w żaden sposób nie zostały dookreślone przez ustawodawcę na gruncie analizowanej ustawy (np. w postaci definicji legalnej sensu stricto). 
Przepis art. 18c ust. 2 pkt 4 PromZatrU posługuje się pojęciem dokumentu elektronicznego. Zgodnie z art. $77^{3}$ ustawy z dnia 23 kwietnia 1964 r. - Kodeks cywilny (tekst jedn. Dz.U. z 2019 r., poz. 1145) , dokumentem jest nośnik informacji umożliwiający zapoznanie się z jej treścią". Z kolei w art. 3 pkt 35 Rozporządzenia Parlamentu Europejskiego i Rady (UE) nr 910/2014 z dnia 23 lipca 2014 r. w sprawie identyfikacji elektronicznej i usług zaufania w odniesieniu do transakcji elektronicznych na rynku wewnętrznym oraz uchylającego dyrektywę 1999/93/WE (Dz.Urz. UE z 2014 r., L 257/73) zamieszczono definicję dokumentu elektronicznego, który do celów tegoż rozporządzenia „oznacza każdą treść przechowywaną w postaci elektronicznej, w szczególności tekst lub nagranie dźwiękowe, wizualne lub audiowizualne"1. W porównaniu do kodeksowego rozumienia dokumentu (w ujęciu uniwersalnym) druga ze wskazanych definicji zdaje się utożsamiać informację z jej treścią, przy czym owa rozbieżność nie ma większego znaczenia dla głównego przedmiotu niniejszych rozważań, biorąc pod uwagę brzmienie art. 18c ust. 2 pkt 4 PromZatrU. Przepis ten bowiem wprost nawiązuje do informacji (nie treści), która ma być gromadzona w postaci dokumentu elektronicznego.

Informacja o wolnych i poszukiwanych miejscach pracy dla art. 18c ust. 2 pkt 4 PromZatrU jest pojęciem centralnym, przy czym również i ono rodzi wątpliwości natury interpretacyjnej. Pomijając już fakt, że sama informacja w ujęciu prawnym bywa bardzo często odmiennie rozumiana (Barański 2017a), w tym miejscu przede wszystkim należy zasygnalizować dużą niekonsekwencję prawodawcy w posługiwaniu się terminem ,miejsce pracy”. Zasadniczo miejsce pracy definiowane jest w nauce prawa pracy jako przestrzeń, w ramach której odbywa się proces świadczenia pracy, przy czym przepisy prawa pracy o randze ustawy nie zawierają definicji legalnej sensu stricto tego pojęcia (Książek 2013, 21; Zieliński 1986, 205) $)^{2}$. Potocznie określenie to używane jest również jako synonim stosunku pracy (Książek 2013, 22). Tym właśnie potocznym rozumieniem pojęcia miejsca pracy, jednak nie ograniczonym wyłącznie do stosunku pracy, ale obejmującym jakiekolwiek zatrudnienie (pracownicze, niepracownicze), zdaje się posługiwać prawodawca nie tylko na gruncie art. 65 ust. 1 zd. 1 Konstytucji Rzeczypospolitej Polskiej z dnia 2 kwietnia 1997 r. (Dz.U. z 1997 r. Nr 78, poz. 483 ze zm.) $)^{3}$, ale także w ramach analizowanego art. 18c ust. 2 pkt 4 PromZatrU.

\footnotetext{
${ }^{1}$ Rozporządzenie to ma zasięg ogólny oraz wiąże w całości i jest bezpośrednio stosowane we wszystkich państwach członkowskich Unii Europejskiej.

${ }^{2}$ Zgodnie z $§ 2$ pkt 7 b rozporządzenia Ministra Pracy i Polityki Socjalnej z dnia 26 września 1997 r. w sprawie ogólnych warunków bezpieczeństwa i higieny pracy (tekst jedn. Dz.U. z 2003 r. $\mathrm{Nr} 169$, poz. 1650 ze zm.) miejscem pracy jest miejsce wyznaczone przez pracodawcę, do którego pracownik ma dostęp w związku z wykonywaniem pracy.

${ }^{3}$ Zgodnie z tym przepisem „każdemu zapewnia się wolność wyboru i wykonywania zawodu oraz wyboru miejsca pracy".
} 
Dokonywanie czynności faktycznych w zakresie gromadzenia i udostępniania informacji w polskim systemie prawa również nie jest pojmowane jednolicie. Pewne podobieństwo regulacji względem analizowanego aktu normatywnego występuje na gruncie ustawy z dnia 6 lipca 2001 r. o usługach detektywistycznych (tekst jedn. Dz.U. z 2018 r., poz. 2163 ze zm.), gdzie zgodnie z art. 2 ust. 1 tejże ustawy usługami detektywistycznymi są czynności polegające na uzyskiwaniu, przetwarzaniu i przekazywaniu określonych w ustawie informacji, w formach i zakresach niezastrzeżonych dla organów i instytucji państwowych na mocy odrębnych przepisów. W tym ostatnim przepisie ustawodawca zdaje się odwoływać do potocznego rozumienia analizowanych pojęć $c^{4}$. Nie można jednak przy tym zapominać, że świadczenie usług określonych w art. 18c ust. 2 pkt 4 PromZatrU wymaga stosowania Rozporządzenia Parlamentu Europejskiego i Rady (UE) 2016/679 z dnia 27 kwietnia 2016 r. w sprawie ochrony osób fizycznych w związku z przetwarzaniem danych osobowych i w sprawie swobodnego przepływu takich danych oraz uchylenia dyrektywy 95/46/WE (Dz.Urz. UE z 2016 r., L 119/1), które definiuje „przetwarzanie” jako „operację lub zestaw operacji wykonywanych na danych osobowych lub zestawach danych osobowych w sposób zautomatyzowany lub niezautomatyzowany, taką jak zbieranie, utrwalanie, organizowanie, porządkowanie, przechowywanie, adaptowanie lub modyfikowanie, pobieranie, przeglądanie, wykorzystywanie, ujawnianie poprzez przesłanie, rozpowszechnianie lub innego rodzaju udostępnianie, dopasowywanie lub łączenie, ograniczanie, usuwanie lub niszczenie". O ile zatem w ramach ustawy o usługach detektywistycznych odróżnia się przetwarzanie informacji od uzyskiwania i przekazywania informacji, przy czym pojęcia te są równorzędne względem siebie, o tyle na gruncie ostatnio przytoczonego rozporządzenia zakres pojęciowy przetwarzania informacji jest znacznie szerszy i obejmuje między innymi zbieranie i udostępnianie określonych informacji ${ }^{5}$. Patrząc przez pryzmat przepisu art. 18c ust. 2 pkt 4 PromZatrU należy wskazać, że skoro ustawodawca zdecydował się na wymienienie jedynie gromadzenia i udostępniania informacji, pomijając przy tym zupełnie przetwarzanie informacji (w rozumieniu ustawy o usługach detektywistycznych), to tym samym znacznie zawęził katalog czynności, które w oparciu o ten przepis mogą być dokonywane. Zasadniczo nie powinno zatem rodzić wątpliwości, że usługa uregulowana w art. 18c ust. 2 pkt 4 PromZatrU nie obejmuje takich czynności jak organizowanie, porządkowanie, adaptowanie lub modyfikowanie informacji o wolnych i poszukiwanych miejscach pracy.

${ }^{4} \mathrm{~W}$ tym ujęciu ,gromadzenie” oznacza przede wszystkim zbieranie i składanie w jednym miejscu jakichś rzeczy, a „udostępnianie” definiowane jest jako ułatwienie kontaktu z czymś lub umożliwienie korzystanie z czegoś. Zob.: https://sjp.pwn.pl/slowniki/gromadzi\%C4\%87.html [dostęp 23.08.2019]; https://sjp.pwn.pl/szukaj/udost\%C4\%99pni\%C4\%87.html [dostęp 23.08.2019].

${ }^{5}$ Podział podobny do treści wskazanego rozporządzenia występuje na gruncie ustawy z dnia 5 sierpnia 2010 r. o ochronie informacji niejawnych (tekst jedn. Dz.U. z 2019 r., poz. 742 ze zm.). 
Z kolei system informatyczny zdefiniowany został w art. 2 pkt 3 ustawy z dnia 18 lipca 2002 r. o świadczeniu usług drogą elektroniczną (tekst jedn. Dz.U. z 2019 r., poz. 123 ze zm.) i oznacza zespół współpracujących ze sobą urządzeń informatycznych (tzw. hardware) i oprogramowania (tzw. software), ,zapewniający przetwarzanie i przechowywanie, a także wysyłanie i odbieranie danych poprzez sieci telekomunikacyjne za pomocą właściwego dla danego rodzaju sieci telekomunikacyjnego urządzenia końcowego w rozumieniu ustawy z dnia 16 lipca 2004 r. - Prawo telekomunikacyjne (Dz.U. z 2018 r., poz. 1954 i 2245 z późn. zm.)" Należy przy tym zaznaczyć, że zakres pojęciowy systemu informatycznego nie został ograniczony do środków komunikacji elektronicznej o charakterze indywidualnym.

\section{NASTRECZENIE SPOSOBNOŚCI DO ZAWARCIA UMOWY Z INNĄ OSOBĄ A POŚREDNICZENIE PRZY JEJ ZAWARCIU (BIERNE POŚREDNICTWO PRACY A CZYNNE POŚREDNICTWO PRACY)}

W nauce prawa cywilnego wyrażane są poglądy, że czynności faktyczne dokonywane przez pośrednika mogą polegać na nastręczeniu sposobności do zawarcia umowy z inną osobą lub pośredniczeniu przy jej zawarciu (Burzak 1992, 15-16; Ogiegło 1994, 253; Rott-Pietrzyk 2006, 281; Świerczyński 1999, 20-21)7, co stanowi jednoznaczne nawiązanie do przedwojennej regulacji umowy o pośrednictwo zwykłe (Kosiński, Skąpski, Zoll 1948, 415-416; Longchamps de Bérier $1999,559)^{8}$. W ramach polskiego prawa zobowiązań nigdy nie powstał jednak zamknięty katalog, w którym enumeratywnie określone zostałyby wszystkie czynności dokonywane przez pośrednika. Niemniej w piśmiennictwie od dłuższego

${ }^{6}$ Sieć telekomunikacyjną stanowią natomiast „systemy transmisyjne oraz urządzenia komutacyjne lub przekierowujące, a także inne zasoby, w tym nieaktywne elementy sieci, które umożliwiają nadawanie, odbiór lub transmisję sygnałów za pomocą przewodów, fal radiowych, optycznych lub innych środków wykorzystujących energię elektromagnetyczną, niezależnie od ich rodzaju" (art. 2 pkt 35 ustawy z dnia 16 lipca 2004 r. - Prawo telekomunikacyjne, tekst jedn. Dz.U. z 2018 r., poz. 1954 ze zm.). Telekomunikacyjnym urządzeniem końcowym jest z kolei „urządzenie telekomunikacyjne przeznaczone do podłączenia bezpośrednio lub pośrednio do zakończeń sieci” (art. 2 pkt 43 PrTelU). W literaturze podkreśla się, że najprostszym przykładem takiego urządzenia będzie modem/router pozwalający użytkownikowi podłączyć się do Internetu, lub aparat telefoniczny pozwalający korzystać z usług telefonii komórkowej (Frań-Adamek 2002).

${ }^{7}$ Podobny pogląd wyrażany jest również w orzecznictwie (wyrok SA w Katowicach z 18.01.1994 r., I ACr 823/93, Orzecznictwo Sądów Apelacyjnych i Sądu Najwyższego 1994, nr 11-12, s. 45-48).

${ }^{8}$ Rozporządzenie Prezydenta Rzeczypospolitej z 27 października 1933 r. - Kodeks zobowiązań (Dz.U. Nr 82, poz. 598 ze zm.). Przepis art. 517 k.z. stanowił, że „kto przyrzeka drugiemu wynagrodzenie za nastręczenie sposobności do zawarcia umowy z inną osobą, albo za pośredniczenie przy zawarciu takiej umowy, obowiązany jest zapłacić wynagrodzenie tylko wtedy, gdy umowa zostanie zawarta wskutek zabiegów pośrednika". 
czasu podejmowane są próby przykładowego wskazania czynności faktycznych dokonywanych w ramach pośrednictwa (Barański 2010, 14-15; Świerczyński 1999, 15).

Nastręczenie przez pośrednika sposobności do zawarcia umowy może w szczególności polegać na „wskazaniu potencjalnego kontrahenta, dostarczaniu informacji o stanie jego stosunków majątkowych, uzyskiwaniu i przekazywaniu przyrzekającemu wynagrodzenie informacji o ofertach, jakimi zainteresowani są ewentualni kontrahenci, wskazaniu przedmiotu umowy, a także ułatwianiu spotkania ewentualnych kontrahentów" (Barański 2011, 20). Nastręczenie sposobności w tym rozumieniu sprowadza się zatem do udzielania kontrahentowi pośrednika ,uprzednio mu nieznanych informacji o możliwości zawarcia umowy” (Świerczyński 1999, 21).

Pośredniczenie przy zawarciu umowy definiowane jest natomiast jako ,prowadzenie lub udział pośrednika w negocjacjach mających na celu zawarcie umowy, skłanianie osoby trzeciej do przyjęcia oferty lub obu stron do wzajemnych ustępstw i zmian oferty, przygotowywanie oferty i doręczanie jej osobie trzeciej, ustalanie treści umowy, przygotowywanie odpowiednich dokumentów, ułatwianie zawarcia umowy w odpowiedniej formie" (Barański 2011, 20)9. W obszarze tych działań zadaniem pośrednika jest wywołanie takiego stanu psychicznego u potencjalnego kontrahenta przyrzekającego wynagrodzenie, który polegałby na wyrażaniu przez niego jak największej gotowości do zawarcia umowy w kształcie uzgodnionym przez obie strony (Świerczyński 1999, 21).

Możliwość i zasadność skorzystania z dorobku nauki prawa cywilnego celem ustalenia zakresu pojęciowego pośrednictwa pracy potwierdził Sąd Najwyższy w uchwale z 5.10.1995 r. (III CZP 131/95, LEX nr 14729)10. Również w nauce

${ }^{9} \mathrm{Z}$ kolei w przedwojennej literaturze sformułowany został pogląd, że „pośredniczenie ma miejsce, jeżeli pośrednik łączy dwie strony, które powzięły już bez jego interwencji zamiar dokonania transakcji”, natomiast nastręczenie sposobności do zawarcia umowy obejmuje taką sytuację, w której przyrzekający wynagrodzenie chce zawrzeć umowę z osobą trzecią, która to osoba z początku w ogóle nie ma zamiaru dokonywania tej czynności prawnej, a uczyni to dopiero w wyniku zabiegów pośrednika (Korzonek, Rosenblüth, 1073).

${ }^{10}$ Sąd Najwyższy stwierdził jednocześnie, że pośrednictwo pracy „nie musi polegać na jednoczesnym udzielaniu pomocy bezrobotnym i poszukującym pracy oraz zakładom pracy, ale pośrednictwem pracy jest zarówno udzielanie pomocy bezrobotnym i poszukującym pracy w uzyskaniu odpowiedniego zatrudnienia, bez jednoczesnego udzielania pomocy zakładom pracy w znalezieniu odpowiednich pracowników, jak i udzielanie takiej pomocy bez jednoczesnego udzielania pomocy bezrobotnym i poszukującym pracy w uzyskaniu odpowiedniego zatrudnienia”. Silny związek między pośrednictwem zwykłym i pośrednictwem pracy widoczny był zresztą na gruncie samego Kodeksu zobowiązań. Zgodnie z art. 519 § 1 k.z. ,jeżeli za nastręczenie sposobności do zawarcia umowy o pracę, o najem mieszkania lub o zbycie nieruchomości, albo za pośrednictwo przy zawarciu takich umów umówiono się o wynagrodzenie niewspółmiernie wysokie, sąd na wniosek dłużnika może je obniżyć". Z kolei art. 522 k.z. stanowił, że przepisy działu Kodeksu zobowiązań regulującego pośrednictwo zwykłe ,nie uchybiają odmiennym przepisom o prawach i obowiązkach pośredników i ajentów handlowych i giełdowych oraz zawodowych pośredników pracy”. 
prawa pracy podnosi się, że pośrednictwo pracy może sprowadzać się jedynie do tzw. biernego pośrednictwa pracy, ograniczającego się do ,rejestrowania wolnych miejsc pracy i osób poszukujących pracy oraz udzielania o tym informacji zainteresowanym" (Włodarczyk 2002, 53). Z kolei czynne pośrednictwo pracy definiowane jest jako aktywna pomoc w poszukiwaniu odpowiedniego zatrudnienia lub odpowiednich pracowników (Włodarczyk 2002, 53). Bierne pośrednictwo pracy jest zatem niczym innym jak cywilnoprawnym nastręczeniem sposobności do zawarcia umowy, a czynne pośrednictwo pracy jest tożsame z cywilnoprawnym pośredniczeniem przy zawarciu umowy.

Jednocześnie należy podkreślić, że w nauce prawa cywilnego wyrażany jest pogląd, iż zarówno nastręczenie sposobności, jak i pośredniczenie przy zawarciu umowy może być przez pośrednika dokonywane przy pomocy różnych środków komunikacji, ale zasadniczo o charakterze indywidualnym (Rott-Pietrzyk 2006, $281)^{11}$. Pośrednictwo pracy owego ograniczenia jednak nie zna, skoro zgodnie $\mathrm{z}$ art. 18 ust. 1 pkt 1 lit. b PromZatrU usługi te mogą polegać na upowszechnianiu ofert pracy ${ }^{12}$.

\section{REŻIM PRAWNY UMOWY O ŚWIADCZENIE USLUG WYMIENIONYCH W ART. 18C UST. 2 PKT 4 PromZatrU}

Zgodnie z art. 750 k.c. „do umów o świadczenie usług, które nie są uregulowane innymi przepisami, stosuje się odpowiednio przepisy o zleceniu". W literaturze podkreśla się, że do umów uznawanych za umowy o świadczenie usług objętych regulacją art. 750 k.c. należą między innymi umowy o zebranie (opracowanie)

${ }^{11}$ Jako przykłady wymienia się telefon, pocztę elektroniczną, komunikator internetowy. Należy przy tym podkreślić, że w orzecznictwie wyrażany jest pogląd, iż Internet jest miejscem publicznym (wyrok Sądu Najwyższego z 17.04.2018 r., IV KK 296/17, LEX nr 2481975).

${ }^{12}$ Potwierdza to również stanowisko Ministerstwa Pracy i Polityki Społecznej z dnia 25 lutego 2013 r., zgodnie z którym prowadzenie działalności polegającej na stworzeniu mechanizmu, w którym przyjmuje się od pracodawców informację o poszukiwanych pracownikach, a także przyjmuje się od osób poszukujących pracy informację o posiadanych kwalifikacjach, a następnie w czynny sposób doprowadza się do kontaktu pracodawcy z osobą poszukującą pracy, „nosi znamiona prowadzenia działalności gospodarczej w zakresie świadczenia usług pośrednictwa pracy. [...] W przedmiotowym przypadku nie ma zastosowania przepis art. 18c ust. 2 pkt 4 ustawy o promocji zatrudnienia i instytucjach rynku pracy, który nie wymaga wpisu do rejestru agencji zatrudnienia od podmiotów gromadzących w postaci dokumentu elektronicznego i udostępniającego informację o wolnych i poszukiwanych miejscach pracy za pośrednictwem systemów informatycznych. Czym innym jest bowiem gromadzenie i udostępnianie informacji o wolnych i poszukiwanych miejscach pracy na zasadzie swobodnego dostępu do tych informacji dla każdej ze stron i możliwości samodzielnego kontaktu między nimi, a czym innym aktywne uczestniczenie przez podmiot gospodarczy gromadzący informację o wolnych i poszukiwanych miejscach pracy w kontaktowaniu i w rezultacie kojarzeniu pracodawcy z osobami poszukującymi pracy". Zob.: http://www.wup.gdansk. pl/g2/2014_07/6277ea4ed415405c193 5a20a455f17e7.pdf [dostęp 23.08.2019]. 
określonych informacji i ich udostępnienie (Gawlik, Pazdan 1976, 164; Ogiegło $1989,169)^{13}$. Przepis ten jednak nie jest jedyną drogą poszukiwania reżimu prawnego dla zobowiązania, którego przedmiotem są usługi informacyjne.

W wyroku z 28.10.1999 r. (II CKN 530/98, LEX nr 39489) Sąd Najwyższy wskazał, że w pierwszej kolejności do nienazwanych umów o świadczenie usług należy per analogiam stosować przepisy normujące zbliżone im konstrukcyjnie umowy nazwane. Zdaniem Sądu Najwyższego przepisy regulujące umowę zlecenia mogą być z tego względu stosowane na podstawie art. 750 k.c. „do nienazwanych umów o świadczenie usług tylko w wypadku braku podstaw do analogicznego stosowania do nich przepisów normujących umowy nazwane". Z kolei w nauce prawa cywilnego sformułowany został pogląd, że za punkt wyjścia należy przyjąć art. 750 k.c.; wyłączenie odpowiedniego stosowania przepisów o zleceniu i zastosowanie per analogiam przepisów innych umów nazwanych możliwe jest dopiero wtedy, gdy konkretna umowa nienazwana, po uprzednim przeanalizowaniu konstrukcji umowy zlecenia przez pryzmat art. 750 k.c., okazuje się wyraźnie odmienna od umowy zlecenia (Rott-Pietrzyk 2000, 395-396). Nie rozstrzygając $w$ tym miejscu, który model analogicznego stosowania przepisów umów nazwanych względem nienazwanych umów o świadczenie usług jest prawidłowy, podkreślić należy, że oba modele „prowadzą do właściwego rozstrzygnięcia, albowiem dają możliwość odejścia od stosowania przepisów o zleceniu" (Rott-Pietrzyk 2000, 396).

Autor niniejszego opracowania podziela pogląd, zgodnie z którym przepis art. 750 k.c. nie posiada mocy bezwzględnie obowiązującej, co jednocześnie dopuszcza możliwość stosowania per analogiam do nienazwanych umów o świadczenie usług przepisów dotyczących innych niż zlecenie umów nazwanych. Odmiennie reżimu prawnego należy poszukiwać nie tylko, co oczywiste, dla niektórych umów nazwanych (np. umowy agencyjnej w zakresie tzw. agencji pośredniczej), ale również dla umowy o pośrednictwo zwykłe, będącej obecnie nienazwaną umową o świadczenie usług (Barański 2011, 24-25; Barański 2016, 6-7; Barański 2017b, 1-3; Grzybczyk 1998, 58; Rott-Pietrzyk 2000, 395-396; wyrok SN z 28.10.1999 r., II CKN 530/98, LEX nr 39489). Stąd też tak istotne jest określenie, czy konkretna umowa o świadczenie usług informacyjnych wymienionych $\mathrm{w}$ art. $18 \mathrm{c}$ ust. 2 pkt 4 PromZatrU stanowi jednocześnie pośrednictwo pracy. Gdyby bowiem udzielić odpowiedzi twierdzącej, umowa ta wykazywałaby silne związki z umową agencyjną, która tym samym wyznaczałaby analizowanej umowie reżim prawny ${ }^{14}$. W przeciwnym razie umowa ta, jako „standardowa”

${ }^{13}$ Sformułowany pogląd pokrywa się z tezą Sądu Najwyższego sformułowaną w uzasadnieniu uchwały z 22.01.2003 r. (I KZP 43/02, Wokanda 2003, nr 7-8, s. 36), w której Sąd Najwyższy stwierdził, że „przekazanie informacji stanowi [...] usługę, za którą przekazujący pobiera stosowną opłatę, w której mieści się zarówno cena informacji, jak i należność za jej przekazanie”.

${ }^{14}$ Zgodnie z art. 758 § 1 k.c. ,,przez umowę agencyjną przyjmujący zlecenie (agent) zobowiązuje się, w zakresie działalności swego przedsiębiorstwa, do stałego pośredniczenia, 
umowa o świadczenie usług informacyjnych, przedmiotem której nie byłoby pośrednictwo pracy, stanowiłaby umowę najbardziej zbliżoną do umowy zlecenia, co powodowałoby konieczność odpowiedniego stosowania względem tej umowy przepisów o zleceniu.

\section{PODSUMOWANIE}

Sens konstrukcji pośrednictwa pracy w możliwie najszerszym znaczeniu sprowadza się do umożliwienia zaistnienia określonego stosunku prawnego (zatrudnienia) pomiędzy kontrahentem pośrednika a osobą trzecią, bez względu na to, czy potrzebne informacje przekazywane są kontrahentowi pośrednika w drodze komunikacji indywidualnej czy też poprzez środki, do których ma dostęp szersze grono odbiorców (np. poprzez zamieszczenie na internetowych tablicach ogłoszeniowych). Z całą pewnością cel usług informacyjnych nie zawsze musi koncentrować się na umożliwieniu dokonania określonej dwustronnej czynności prawnej, której stronami będą kontrahent świadczeniodawcy oraz osoba trzecia. W przypadku usług uregulowanych w art. 18c ust. 2 pkt 4 PromZatrU ich cel został jednak pośrednio wskazany poprzez określenie rodzaju informacji gromadzonych i udostępnianych przez świadczeniodawcę. Skoro są to informacje o wolnych i poszukiwanych miejscach pracy, to należy przyjąć, że usługi te zazwyczaj świadczone będą jako nastręczenie sposobności do zawarcia umowy. Jednocześnie dopuścić należy objęcie przedmiotową regulacją także i takich umów, których przedmiotem będzie gromadzenie i udostępnianie informacji o wolnych i poszukiwanych miejscach pracy, na przykład na cele statystyczne czy też w ramach tzw. wywiadowni gospodarczych ${ }^{15}$. Przez pryzmat dotychczasowych rozważań należy zatem przyjąć, że umowa o świadczenie usług wymienionych w art. $18 \mathrm{c}$ ust. 2 pkt 4 PromZatrU jedynie co do zasady stanowić będzie rodzaj umowy o świadczenie usług pośrednictwa pracy. Jak podkreślono już wcześniej,

za wynagrodzeniem, przy zawieraniu z klientami umów na rzecz dającego zlecenie przedsiębiorcy albo do zawierania ich w jego imieniu”. W literaturze podkreśla się, że „istotą umowy o pośrednictwo zwykłe jest dokonywanie przez pośrednika wyłącznie czynności faktycznych, mających na celu doprowadzenie do zawarcia jednej umowy lub określonej liczby umów między osobą, na rzecz której działa, a osobą trzecią. Pośrednik otrzymuje od kontrahenta wynagrodzenie, jeżeli ten ostatni, w wyniku działań pośrednika, zdecyduje się na zawarcie umowy z osobą trzecią" (Barański 2011, 20). Umowa o pośrednictwo zwykłe, z uwagi na jej przedmiot, wykazuje zatem duże podobieństwo względem umowy agencyjnej w zakresie tzw. agencji pośredniczej i jednocześnie jest wyraźnie odmienna od umowy zlecenia (Barański 2011, 24-25). Jak zauważa A. Burzak, „zakresy działania zleceniobiorcy (najczęściej będącego pełnomocnikiem) - zawarcie umowy w imieniu reprezentowanego, i pośrednika - stworzenie sposobności do zawarcia umowy, nie są tożsame, a wręcz rozłączne" (Burzak 1992, 16).

${ }^{15}$ Zupełnie odrębną kwestią pozostaje w takich przypadkach problematyka dopuszczalności przetwarzania danych osobowych. 
w takiej sytuacji reżim prawny tej umowy wyznaczać będą przepisy dotyczące umowy agencyjnej. Nie ma natomiast możliwości stwierdzenia, że przedmiotowe usługi każdorazowo stanowić będą usługi pośrednictwa pracy. Tym samym to od okoliczności konkretnego przypadku (treści umowy) będzie zależało, czy usługi wymienione w art. 18c ust. 2 pkt 4 PromZatrU mieszczą się w zakresie pojęciowym pośrednictwa pracy czy też wręcz przeciwnie, stanowią one usługi informacyjne, których nie można zakwalifikować jako pośrednictwo pracy.

\section{BIBLIOGRAFIA}

Barański, Michał. 2010. „Konstrukcja prawna umów o pośrednictwo”. Rejent 9: 9-32.

Barański, Michał. 2011. „Umowa o pośrednictwo zwykłe”. Przegląd Ustawodawstwa Gospodarczego 4: 20-30.

Barański, Michał. 2016. „Umowa o pośrednictwo zwykłe w wybranych systemach prawnych”. Transformacje Prawa Prywatnego 1: 5-25.

Barański, Michał. 2017a. Informacja w ujęciu prawnym przez pryzmat zagadnień terminologicznych. Katowice: Wydawnictwo Uniwersytetu Śląskiego.

Barański, Michał. 2017b. „Obowiązki oraz odpowiedzialność kontraktowa stron umowy o pośrednictwo zwykłe". W Prawo prywatne wobec wyzwań współczesności. Księga pamiątkowa dedykowana Profesorowi Leszkowi Ogiegle. Red. Mariusz Fras, Piotr Ślęzak. 1-16. Warszawa: C.H. Beck

Burzak, Andrzej. 1992. „Umowa o pośrednictwo (I)”. Przegląd Prawa Handlowego 2: 14-19.

Frań-Adamek, Aneta. 2002. Świadczenie usług droga elektroniczną. Komentarz. LEX/el. [dostęp 12.07.2018].

Gawlik, Bogusław, Maksymilian Pazdan. 1976. Umowy licencyjne w obrocie międzynarodowym. Katowice: Wojewódzki Klub Techniki i Racjonalizacji przy WRZZ i OW NOT.

Grzybczyk, Grażyna. 1998. „Różne formy pośrednictwa”. Rejent 2: 45-58.

Korzonek, Jan, Ignacy Rosenblüth. 1934. Kodeks zobowiązań. Komentarz. T. 1. Kraków: Księgarnia Powszechna.

Kosiński, Stefan, Józef Skąpski, Fryderyk Zoll. 1948. Zobowiąania w zarysie wedlug polskiego kodeksu zobowiązań. Podręcznik poddany rewizji i wykończony przy współudz. Stefana Kosińskiego i Józefa Skapskiego. Warszawa: Gebethner i Wolff.

Książek, Daniel. 2013. Miejsce pracy jako istotny element umowy o pracę. Warszawa: Wolters Kluwer Polska.

Longchamps de Bérier, Roman. 1999. Polskie prawo cywilne. Zobowiazania. Lwów 1939, wyd. 2 anastatyczne. Poznań: Ars Boni et Aequi.

Ogiegło, Leszek. 1989. Usługi jako przedmiot stosunków obligacyjnych. Katowice: Wydawnictwo Uniwersytetu Śląskiego.

Ogiegło, Leszek. 1994. „Odpowiedzialność kontraktowa pośrednika”. W Rozprawy z polskiego i europejskiego prawa prywatnego. Księga pamiątkowa ofiarowana Profesorowi Józefowi Skąskiemu. Red. Andrzej Mączyński, Maksymilian Pazdan, Adam Szpunar. Kraków: Secesja.

Rott-Pietrzyk, Ewa. 2000. „Glosa do wyroku Sądu Najwyższego z dnia 28 października 1999 r. II CKN 530/98". Orzecznictwo Sądów Polskich 7-8: 395-396.

Rott-Pietrzyk, Ewa. 2006. Agent handlowy - regulacje polskie i europejskie. Warszawa: C.H. Beck. Świerczyński, Tomasz. 1999. „Charakter prawny umowy o pośrednictwo”. Przeglad Prawa Handlowego 1: 15-25. 
Włodarczyk, Mirosław. 2002. Pośrednictwo pracy. Studium prawno-społeczne. Łódź: Wydawnictwo Uniwersytetu Łódzkiego.

Zieliński, Tadeusz. 1986. Prawo pracy. Zarys systemu. Część. 2: Prawo stosunku pracy. WarszawaKraków: Państwowe Wydawnictwo Naukowe.

\author{
Michat Barański
}

\title{
DIFFERENCES BETWEEN PRIVATE INTERMEDIATION IN EMPLOYMENT AND PROVIDING INFORMATION SERVICES ABOUT EMPLOYMENT THROUGH TELECOMMUNICATIONS SYSTEMS
}

\begin{abstract}
Provisions of art. 18 (1) point 1 and art. 18c (2) point 4 of the Act on promotion of employment and labour market institutions of 20 April 2004, due to their far-reaching imprecision, raise the question what the mutual relationship between these provisions is, in particular, whether the services listed in Article 18c (2) point 4 of the mentioned Act fall within the conceptual scope of private intermediation in employment, or, on the contrary, they constitute services that cannot be classified as private intermediation in employment. The article analyzes in detail the regulations related to collecting (in the form of an electronic document) and providing information about employment through telecommunications systems. The difference between passive and active intermediation in employment has been shown, and an attempt has been made to indicate the legal regime of the contract for provision of services listed in art. 18c (2) point 4 of the mentioned Act.
\end{abstract}

Keywords: intermediation in employment, information services, ICT system, electronic document, employment. 